\title{
KEEFEKTIFAN PEMBELAJARAN MATEMATIKA BERBASIS KONTRUKTIVISME PADA MATA KULIAH MATEMATIKA DASAR
}

\author{
Aryo Andri Nugroho \\ Pendidikan Matematika IKIP PGRI Semarang \\ ndrie024mp@gmail.com
}

\begin{abstract}
This research aims to improve mathematics learning achievement of first semester student majoring biology at IKIP PGRI Semarang using mathematics learning based on constructivism in basic mathematics courses. This type of study is a research of Quasy Experimental. The population is the first semester of students majoring in biology education IKIP PGRI Semarang which consists of five classes. By random sampling technique we choose two classes, class $1 \mathrm{~A}$ as a class experiment and class $1 E$ as a control class. Variables in this research are the process skills $(X)$ as the independent variable and learning achievement $(Y)$ as the dependent variable. Data collection had been done by observation and learning achievement tests and for analyzing by comparison and influence tests. The results showed that completeness test has average 70.20 . It means that completeness had been and there is a achievement difference between the experimental class and control class. Beside that, we find that variable of process skill has a positive effect to the learning achievement by regression equation $\hat{Y}=105,599-495 X$ and the effect is $20.3 \%$. It is shown that learning at experiment class is effective.
\end{abstract}

Key words: constructivism, Effective, Basic Mathematics

ABSTRAK. Penelitian ini bertujuan meningkatkan prestasi belajar matematika mahasiswa semester I jurusan pendidikan biologi IKIP PGRI Semarang dengan menggunakan pembelajaran matematika berbasis konstruktivisme pada mata kuliah matematika dasar. Jenis penelitian yang digunakan adalah penelitian Quasy Experimental. Populasi dalam penelitian ini adalah mahasiswa semester I jurusan pendidikan biologi IKIP PGRI Semarang yang terdiri dari lima kelas. Dengan teknik random sampling dipilih dua kelas, kelas 1 A sebagai kelas eksperimen dan kelas $1 E$ sebagai kelas kontrol. Variabel penelitian dalam penelitian ini yaitu keterampilan proses (X) sebagai variabel bebas dan prestasi belajar (Y) sebagai variabel terikat. Cara pengambilan data dengan observasi dan tes prestasi belajar. Olah data dengan uji banding dan uji pengaruh. Hasil penelitian menunjukkan bahwa uji ketuntasan dengan rata-rata 70,20 artinya telah mencapai ketuntasan dan terjadi perbedaan prestasi antara kelas eksperimen dan kelas kontrol serta diperoleh variabel keterampilan proses berpengaruh positif terhadap prestasi belajar dengan persamaan regresi $\hat{Y}=105,599-495 X$ dan pengaruhnya sebesar 20,3\%. Hal tersebut menunjukkan pembelajaran kelas eksperimen mencapai efektif.

Kata Kunci : Konstruktivisme, Efektif, Matematika Dasar 


\section{PENDAHULUAN}

\subsection{Latar Belakang}

Salah satu masalah yang dihadapi dunia pendidikan adalah masih lemahnya proses pembelajaran. Dalam proses pembelajaran anak kurang didorong untuk mengembangkan kemampuan berpikir, mengembangkan karakter dan potensi yang dimiliki, dan memiliki kemampuan memecahkan masalah hidup. Selain itu mahasiswa kurang diarahkan untuk membentuk manusia yang kreatif, inovatif, mandiri dan berjiwa wirausaha (Sanjaya 2008: 2).

Proses pembelajaran yang efektif merupakan harapan semua pihak yang terkait dengan pendidikan. Untuk mencapai hal tersebut, antara lain diperlukan adanya partisipasi aktif dari dosen, mahasiswa dan suasana kelas yang mendukung (kondusif). Menurut Mulyana (2004:19) pembelajaran yang efektif ditandai dengan adanya sikap yang menekankan pada pembelajaran secara efektif. Menurut Guskey (1982) pembelajaran yang efektif ditandai dengan adanya ketercapaian ketuntasan dalam prestasi belajar, adanya pengaruh yang positif antara variabel bebas dengan variabel terikat, adanya perbedaan prestasi antara kelas eksperimen dengan kelas kontrol.

Pembelajaran matematika yang masih menggunakan pembelajaran konvensional masih menempatkan dosen sebagai sumber informasi utama yang berperan dominan dalam proses pembelajaran. Dalam pembelajaran konvensional dosen bertindak sebagai pentransfer ilmu kepada mahasiswanya, mahasiswa dianggap sebagai penerima pengetahuan yang pasif (Suparman, 1997:198). Pengetahuan awal mahasiswa tidak diberi kesempatan untuk berinteraksi dan berpartisipasi dengan benda-benda yang ada di sekitarnya yang dapat berfungsi sebagai sumber belajar, sehingga mahasiswa kurang mampu merelevansikan pengetahuan yang diterima dengan kehidupan sehari-hari.

Mahasiswa akan memahami mata kuliah bila mahasiswa aktif sendiri membentuk atau menghasilkan pengertian dari hal-hal yang diinderanya, penginderaan dapat terjadi melalui penglihatan, pendengaran, penciuman dan sebagainya. Pengertian yang dimiliki mahasiswa merupakan bentukannya sendiri 
dan bukan hasil bentukan orang lain. Piaget dengan konstruktivisnya berpendapat bahwa pengetahuan akan dibentuk oleh mahasiswa apabila mahasiswa dengan obyek/orang, dan mahasiswa selalu mencoba membentuk pengertian dari interaksi tersebut.

Hasil penelitian Arif (2010) menyatakan bahwa penggunaan konstruktivisme dalam pembelajaran mempengaruhi prestasi, keaktifan dan kemampuan guru mengelola pembelajaran. Melalui pembelajaran konstruktivisme, mahasiswa ditempa, sehingga memahami teori, latihan, dan dapat mengaplikasikan teori dan latihan tersebut dalam dunia nyata. Hasil penelitian yang sama juga diperoleh pada penelitian Prayito (2011) dan Aryo (2011).

Salah satu mata kuliah pada kurikulum jurusan pendidikan biologi IKIP PGRI Semarang yaitu matematika dasar. Pada mata kuliah matematika dasar mahasiswa banyak menemui kendala dalam memahaminya sehingga perlu ada perlakuan yang bisa meningkatkan prestasi belajar mahasiswa. Dengan pembelajaran konstruktivis diharapkan mahasiswa dapat memahami materi yang diberikan oleh dosennya karena dalam pembelajaran lebih menekankan pemahaman konsep dengan cara mengkonstruk langkah-langkah penyelesaian permasalahannya. Dalam kegiatan penelitian ini akan di lihat keterampilan proses mahasiswa dalam menyelesaikan masalah dengan mengkonstruk atau membangun permasalahan yang ada. Dengan pembelajaran matematika yang dibangun oleh mahasiswa sendiri nantinya akan menjadi lebih efektif. Dalam penelitian ini peneliti memaknai perlunya adanya pembelajaran matematika berbasis konstruktivisme pada mata kuliah matematika dasar sehingga diharapkan pembelajaran menjadi efektif.

\subsection{Rumusan Masalah}

Dari uraian latar belakang tersebut, permasalahan yang muncul dan akan dikaji dalam penelitian ini adalah sebagai berikut.

a. Apakah pembelajaran matematika berbasis konstruktivisme pada mata kuliah matematika dasar dapat mencapai tuntas? 
b. Apakah terdapat pengaruh keterampilan proses pada pembelajaran matematika berbasis konstruktivisme pada mata kuliah matematika dasar terhadap prestasi belajar mahasiswa?

c. Apakah pembelajaran matematika berbasis konstruktivisme pada mata kuliah matematika dasar lebih baik dari pembelajaran konvensional ?

\subsection{Tujuan}

Berdasarkan uraian pada latar belakang dan rumusan masalah seperti tersebut di atas, dapat dirumuskan tujuan penelitian ini adalah.

a. Untuk mengetahui pembelajaran matematika matematika berbasis konstruktivisme pada mata kuliah matematika dasar mencapai tuntas.

b. Untuk mengetahui pengaruh keterampilan proses pada pembelajaran matematika berbasis konstruktivisme pada mata kuliah matematika dasar terhadap prestasi belajar mahasiswanya.

c. Untuk mengetahui pembelajaran matematika berbasis konstruktivisme pada mata kuliah matematika dasar lebih baik dari pembelajaran konvensional pada kelas reguler.

\subsection{Manfaat Penelitian}

Hasil penelitian ini diharapkan bermanfaat bagi.

a. Terciptanya suasana pembelajaran yang dapat meningkatkan keterampilan mahasiswa sehingga dapat menumbuhkan motivasi dan kreatifitas belajar bagi mahasiswa.

b. Dapat mengetahui keefektifan pembelajaran matematika dengan menggunakan pembelajaran konstruktivisme.

c. Dapat memberi sumbangan yang baik bagi institusi dalam rangka perbaikan proses pembelajaran untuk dapat meningkatkan prestasi mahasiswa

d. Mendapat masukan tentang penelitian yang dapat memajukan institusi. 


\section{METODE PENELITIAN}

\subsection{Jenis Penelitian}

Penelitian ini merupakan penelitian eksperimen jenis Quasi Experimental (Samsudi, 2006: 75) yang bertujuan untuk meningkatkan prestasi belajar mahasiswa pada mata kuliah matematika dasar yang memenuhi kriteria efektif.

\subsection{Populasi dan Sampel Penelitian}

Populasi penelitian adalah semua mahasiswa IKIP PGRI Semarang jurusan pendidikan biologi semester I yang diampu dosen yang sama. Untuk kelas uji coba adalah mahasiswa yang berasal dari kelas 1B semester I tahun ajaran 2011/2012. Sebagai sampel penelitian dalam tahap ini adalah semua mahasiswa kelas 1E (Kontrol) dan 1A (Eksperimen) IKIP PGRI Semarang yang memiliki karakteristik yang sama dengan kelas uji coba. Teknik pengambilan sampel dalam penelitian ini adalah sampel random sampling.

\subsection{Variabel Penelitian}

Dalam penelitian ini variabel bebas $(\mathrm{X})$ adalah keterampilan proses mahasiswa dan variabel terikat $(\mathrm{Y})$ dalam penelitian ini adalah prestasi belajar mahasiswa.

\subsection{Instrumen Penelitian}

Instrumen penelitian adalah alat untuk mengumpulkan data tentang pembelajaran matematika berbasis konstruktivisme pada mata kuliah matematika dasar. Instrumen pada penelitian ini terdiri dari lembar pengamatan keterampilan proses mahasiswa dan lembar tes prestasi belajar.

Sebelum instrumen tes prestasi belajar diberikan kepada mahasiswa, terlebih dahulu dilakukan uji coba instrumen (tes prestasi belajar) untuk melihat validitas dan realibitas instrumen tersebut dan untuk dianalisis daya beda dan tingkat kesukaran soal.

\subsection{Teknik Pengumpulan Data}

Metode pengumpulan data yang dilakukan dalam penelitian ini meliputi data dokumentasi, data prestasi belajar, data keterampilan proses mahasiswa. 


\subsection{Analisis Data}

Data dari variabel keterampilan proses diambil dengan pengamatan, sedangkan data dari variabel prestasi belajar diambil dengan tes. Kemudian suatu pembelajaran dikatakan efektif jika memenuhi ketercapaian pengukuran ketuntasan belajar yang di uji dengan menggunakan uji One Sample Test, adanya pengaruh variabel bebas terhadap variabel terikat yang di uji dengan menggunakan uji regresi, ada perbedaan antara prestasi belajar mahasiswa pada kelas eksperimen lebih tinggi dibandingkan prestasi belajar pada kelas kontrol yang di uji dengan menggunakan uji Independent Sample Test.

\section{HASIL DAN PEMBAHASAN}

\subsection{Hasil}

Data hasil penelitian digunakan untuk mengetahui tingkat keberhasilan pembelajaran yang diukur melalui tiga uji statistika, yaitu uji ketuntasan prestasi belajar, uji pengaruh, dan uji perbedaan yang sebelumnya melalui uji prasyarat. Hasil ketiga uji tersebut dapat dilihat pada penjelasan berikut ini.

\section{a. Uji Prasyarat}

Berdasarkan kemampuan awal mahasiswa yang diambil dari nilai ujian tengah semester kelas 1A dan kelas 1E tahun 2011/2012 dilakukan uji normalitas dengan menggunakan uji Kolmogorov-Smirnov.

Hipotesis

$\mathrm{H}_{0}$ : Variabel adalah normal

$\mathrm{H}_{1}$ : Variabel adalah tidak normal

Uji normalitas menggunakan One Sample kolmogorov-Smirnov Test diperoleh hasil sebagai berikut. Untuk kelas 1A didapat nilai Asymp.Sig = 0,261 sedangkan kelas 1E didapat nilai Asymp.Sig = 0,266 yang keduanya lebih dari $5 \%$ maka $\mathrm{H}_{0}$ diterima. Artinya data kelas $1 \mathrm{~A}$ dan kelas $1 \mathrm{E}$ adalah normal. Untuk pengujian homogenitas kelas $1 \mathrm{~A}$ dan $1 \mathrm{E}$ dipakai uji Independent Sample t Tes.

Hipotesis

$\mathrm{H}_{0}$ : varian kelas $1 \mathrm{~A}=$ varian kelas $1 \mathrm{E}$ 
$\mathrm{H}_{1}$ : varian kelas $1 \mathrm{~A} \neq$ varian kelas $1 \mathrm{E}$

Dari hasil perhitungan didapat nilai sig $=0,223=22,3 \%>5 \%$ maka $_{0}$ diterima, artinya varian kelas 1A dan varian kelas 1E sama atau homogen. Nilai prestasi belajar kelas eksperimen dilakukan uji normalitas dengan menggunakan uji Kolmogorov-Smirnov.

Hipotesis

$\mathrm{H}_{0}$ : Variabel adalah normal

$\mathrm{H}_{1}$ : Variabel adalah tidak normal

Dari perhitungan mendapatkan nilai Asymp.Sig $=0,339=33,9 \%>5 \%$ jadi $\mathrm{H}_{0}$ diterima artinya nilai prestasi belajar kelas eksperimen normal.

\section{b. Uji Ketuntasan Prestasi Belajar}

Dalam penelitian ini, uji ketuntasan prestasi belajar yang diukur adalah uji ketuntasan klasikal. Untuk uji ketuntasan klasikal digunakan uji rata-rata dua pihak. Hipotesis statistiknya seperti berikut ini.

Hipótesis $\mathrm{H}_{0}: \mu=65$ (Rata-rata nilai prestasi belajar mahasiswa sama dengan

$\mathrm{H}_{1}: \mu \neq 65$ (Rata-rata nilai prestasi belajar mahasiswa tidak sama dengan 65)

Dari data TPB selanjutnya dilakukan analisis data uji ketuntasan klasikal menggunakan One Sample Test dan diperoleh nilai sig $=0,027=2,7 \%$ $<5 \%$ ), maka $\mathrm{H}_{0}$ ditolak. Artinya rata-rata nilai prestasi belajar mahasiswa tidak sama dengan 65. Selanjutnya melihat pada One Sample Statistic, dengan nilai rata-rata mean $=70,20$ maka nilai rata-rata ketuntasan belajar kelas eksperimen lebih dari 65.

\section{c. Uji Pengaruh Keterampilan Proses Terhadap Prestasi Belajar}

Untuk menganalisis pengaruh keterampilan proses mahasiswa terhadap prestasi belajar digunakan regeresi linear sederhana dan diperoleh nilai $\mathrm{F}=5$, 843 dan sig $=0,024=2,4 \%$ yang berarti $\mathrm{H}_{0}$ ditolak, artinya persamaan regresi linear.

Besarnya pengaruh keterampilan proses terhadap prestasi belajar dapat dilihat dari nilai nilai $\mathrm{R}$ square $=0,203$ yang berarti $20,3 \%$ prestasi belajar 
mahasiswa dipengaruhi oleh faktor keterampilan proses mahasiswa. Hubungan keterampilan proses terhadap prestasi belajar ditunjukkan pada persamaan regresi. Bentuk persamaan regresinya yaitu $\hat{Y}=105,599-0,495 X$ artinya setiap keterampilan proses $(\mathrm{X})$ meningkat satu satuan maka prestasi belajar ( $\hat{Y}$ ) meningkat sebesar 0,495 .

\section{d. Uji Banding}

Uji banding disini dimaksudkan untuk membandingkan rataan suatu variabel antara kelas eksperimen dan kelas kontrol. Hipotesis yang digunakan seperti berikut ini.

Hipotesis $\mathrm{H}_{0}: \mu_{1}=\mu_{2}$ (rataan kelas eksperimen sama dengan rataan kelas kontrol )

$\mathrm{H}_{1}: \mu_{1} \neq \mu_{2} \quad$ (rataan kelas eksperimen tidak sama dengan rataan kelas kontrol)

Dalam penelitian ini analisis data uji banding menggunakan Independent Sample Test dan diperoleh simpulan bahwa dilihat dari nilai kesamaan dua varians diperoleh $\mathrm{F}=0,569$ dan sig $=0,454=45,4 \%$ (lebih dari $5 \%$ ). Ini berarti $\mathrm{H}_{0}$ diterima, artinya kedua sampel mempunyai varians yang sama. Selanjutnya dipilih Equal variance assumed, diperoleh sig $=0,000=0 \%$ $<5 \%$. Ini berarti $\mathrm{H}_{0}$ ditolak. Artinya kedua populasi mempunyai nilai rata-rata ketuntasan yang berbeda.

Dari hasil TPB dengan uji statistik yaitu uji ketuntasan, uji pengaruh dan uji banding dapat disimpulkan bahwa pembelajaran matematika berbasis konstruktivis efektif.

\subsection{Pembahasan}

Berdasarkan hasil pengujian homogenitas dan normalitas dapat dikatakan bahwa kelas $1 \mathrm{~A}$ dan kelas $1 \mathrm{E}$ adalah kelas yang homogen dan berdistribusi normal. Pelaksanaan penelitian ini diberikan dalam 5 kali pertemuan untuk proses pembelajaran pada kelas eksperimen dan 1 kali pertemuan untuk tes prestasi belajar pada kelas eksperimen dan kelas kontrol. Pembelajaran diampu oleh dosen sekaligus peneliti. Selanjutnya penelitian dilakukan pada kelas eksperimen. Hasil 
penelitian terdiri dari data hasil pengamatan keterampilan proses mahasiswa, data prestasi belajar (TPB) di kelas eksperimen dan data prestasi belajar (TPB) di kelas kontrol. Data-data tersebut selanjutnya dianalisis untuk diketahui ketuntasannya, besar pengaruh, dan kemampuan membedakan antara kelas eksperimen dan kelas kontrol.

\section{a. Ketuntasan Prestasi Belajar}

Ketuntasan prestasi belajar yang diukur adalah ketuntasan secara klasikal. Telah dinyatakan dalam uji ketuntasan klasikal menghasilkan bahwa nilai rata-rata ketuntasan belajar di kelas eksperimen lebih dari 65. Hal ini menunjukkan secara nyata keberhasilan proses pembelajaran berbasis konstruktivisme. Keberhasilan ini disebabkan karena mahasiswa berusaha untuk mengkonstruk dan menyelesaikan permasalahan yang ada.

Hal lain yang menjadi penyebab keberhasilan pembelajaran berbasis konstruktivisme yaitu banyak memberi kesempatan lebih luas pada mahasiswa untuk memecahkan masalah secara runtut dan sistematis sampai dengan ditemukan solusinya. Dari hasil ini membuktikan bahwa pembelajaran matematika berbasis konstruktivisme dapat menuntaskan prestasi belajar mahasiswa.

\section{b. Pengaruh Keterampilan Proses Terhadap Prestasi Belajar}

Keterampilan proses dalam proses pembelajaran adalah suatu kecakapan yang diperoleh akibat langkah-langkah strategi pembelajaran sehingga terjadi perubahan tingkah laku. Peran guru hanya sebagai fasilitator yang dapat membantu mahasiswa jika diperlukan saja. Ini berarti pembelajaran telah menerapkan teori belajar Vygotsky tentang scaffolding yaitu upaya menemukan sendiri cara memecahkan masalah sehingga memungkinkan mahasiswa tumbuh mandiri.

Widyatiningtyas (2010:1) menyatakan bahwa mahasiswa melaksanakan keterampilan proses maka akan sekaligus dikembangkan sikap-sikap yang dikehendaki seperti kreatif, kerjasama, bertanggung jawab, dan berdisplin sesuai dengan penekanan bidang studi yang bersangkutan. Dengan demikian, keterampilan proses merupakan proses pembelajaran yang mengarah kepada 
pengembangan kemampuan-kemampuan mental, fisik, dan sosial yang mendasar sebagai penggerak kemampuan yang lebih tinggi dalam diri individu mahasiswa. Karena itu peningkatan keterampilan proses pada mahasiswa merupakan hal penting yang harus selalu diupayakan agar peningkatan prestasi belajar mahasiswa dapat tercapai secara optimal. Berdasarkan analisis uji pengaruh, telah dapat dibuktikan bahwa keterampilan proses berpengaruh secara linear terhadap prestasi belajar mahasiswa.

Melalui pembelajaran menggunakan pembelajaran matematika berbasis konstruktivisme, dihasilkan pengaruh keterampilan proses terhadap prestasi belajar sebesar 20,3\% dan 70,7\% dipengaruhi oleh faktor lain yang tidak menjadi variabel dalam penelitian ini.

\section{c. Perbedaan kelas eksperimen dengan kelas kontrol}

Berdasarkan hasil membandingkan nilai rata-rata kelas eksperimen dan kelas kontrol dapat disimpulkan bahwa kelas eksperimen mempunyai nilai rata-rata ketuntasan lebih tinggi dibandingan nilai rata-rata ketuntasan kelas kontrol. Ini menunjukkan pembelajaran berbasis konstruktivisme lebih menekankan pada keterampilan dan kreatifitas mahasiswa dalam menyelesaikan permasalahan sehingga terbukti lebih baik dari pembelajaran konvensional yang selama ini dilakukan. Sedangkan pembelajaran membantu mahasiswa dalam menggali informasi-informasi yang berasal dari banyak sumber.

Di sisi lain, dengan pembelajaran berbasis konstruktivisme, proses belajar sangat mungkin berlangsung secara optimal karena proses pembelajaran dapat benar-benar terjadi. Proses pembelajaran berbasis konstruktivisme yang dilakukan pada kelas eksperimen mempunyai kecenderungan keterkaitan yang lebih kuat dibandingkan pembelajaran yang dilakukan pada kelas kontrol.

Dari ketiga komponen ini terbukti bahwa pembelajaran dengan menggunakan pembelajaran matematika berbasis konstruktivisme pada mata kuliah matematika dasar memenuhi tiga hal yaitu : (1) pembelajaran mencapai ketuntasan; (2) ada pengaruh keterampilan proses terhadap prestasi belajar; (3) prestasi belajar kelas eksperimen lebih baik dari kelas kontrol. Menurut 
Guskey karena telah memenuhi 3 hal diatas maka pembelajaran tersebut efektif. Jadi berdasarkan hasil dan pembahasan penelitian diatas maka pembelajaran matematika berbasis konstruktivisme pada mata kuliah matematika dasar adalah efektif.

\section{KESIMPULAN DAN SARAN}

\subsection{Kesimpulan}

Berdasarkan hasil penelitian yang telah diuraikan maka diperoleh kesimpulan bahwa pelaksanaan pembelajaran telah mencapai indikator efektif, yaitu: (1) mencapai ketuntasan pada prestasi belajar mahasiswa; (2) ada pengaruh positif keterampilan proses terhadap prestasi belajar mahasiswa; dan (3) prestasi belajar kelas eksperimen lebih tinggi dibanding prestasi belajar kelas kontrol, maka pelaksanaan pembelajaran matematika berbasis konstruktivisme mencapai efektif.

\subsection{Saran}

Dosen seyogyanya mau mencoba melakukan proses pembelajaran dengan pendekatan konstruktivis sehingga harapannya mahasiswa bisa menyelesaikan permasalahan yang ada secara sistematis dan menambah pengalaman belajar bagi mahasiswa.

\section{DAFTAR PUSTAKA}

Ediyanto, A. (2010). Pengembangan Perangkat Pembelajaran Matematika Humanistik Berbasis Konstruktivisme dan Berbantuan ICT Materi Geometri Dimensi Dua Kelas XI SMK. Tesis Universitas Negeri Semarang.

Guskey, dkk., (1983). The Effectiveness of Mastery Learning Strategies in Undergraduate Educations Courses. Journal of Educational Research,vol.76, No. 4, 210-214.

Mulyana, E. (2004). Kurikulum Berbasis Kompetensi, Bandung; PT. Remaja Rosdakarya.

Nugroho, A.A, dkk (2011). Efektifitas Pembelajaran Matematika Bilingual Berbasis Konstruktivisme Pada Materi Program Linear. Hibah BI IKIP PGRI Semarang 
Piaget, J. (1973). The Child and Reality (W. Mays, Trans). London: Routledge \& Kegan Paul.

Prayito, M. (2011). Pengembangan Perangkat Pembelajaran Matematika Humanistik berbasis Konstruktivisme Berbantuan E-Learning Materi segitiga Kelas VII. Jurnal Aksioma, Vol.2, No. 2, 187-198.

Samsudi. (2009). Disain Penelitian Pendidikan. Semarang : UNNES PRESS.

Sanjaya, W. (2008). Strategi Pembelajaran Berorientasi Standar Proses Pendidikan. Jakarta: Kencana Prenada Media Group.

Suparman, (1997). Desain Instruksional, Jakarta : Dirjen Dikti Depdiknas.

Vygotsky. (1978). Characteristics of Constructivist Learning and Teaching. http:www.stemnet.nf.ca (26/11/2009).

Widyatiningtyas, R. (2010). Peranan Guru dalam Melakukan Penilaian Keterampilan Proses EDUCARE: Jurnal Pendidikan dan Budaya. http://educare.e-fkipunla.net Generated: down load 4 June, 2010, 10:28. 